This item was submitted to Loughborough's Research Repository by the author.

Items in Figshare are protected by copyright, with all rights reserved, unless otherwise indicated.

\title{
Thermo-migration behavior of SAC305 lead-free solder reinforced with fullerene nanoparticles
}

PLEASE CITE THE PUBLISHED VERSION

http://dx.doi.org/10.1007/s10853-016-0234-8

\section{PUBLISHER}

(C) Springer

VERSION

AM (Accepted Manuscript)

\section{PUBLISHER STATEMENT}

This work is made available according to the conditions of the Creative Commons Attribution-NonCommercialNoDerivatives 4.0 International (CC BY-NC-ND 4.0) licence. Full details of this licence are available at: https://creativecommons.org/licenses/by-nc-nd/4.0/

\section{LICENCE}

CC BY-NC-ND 4.0

\section{REPOSITORY RECORD}

Chen, Guang, Li Liu, Juan Du, Vadim V. Silberschmidt, Y.C. Chan, Changqing Liu, and Fengshun Wu. 2019. "Thermo-migration Behavior of SAC305 Lead-free Solder Reinforced with Fullerene Nanoparticles". figshare. https://hdl.handle.net/2134/22918. 
Dear Author,

Here are the proofs of your article.

- You can submit your corrections online, via e-mail or by fax.

- For online submission please insert your corrections in the online correction form. Always indicate the line number to which the correction refers.

- You can also insert your corrections in the proof PDF and email the annotated PDF.

- For fax submission, please ensure that your corrections are clearly legible. Use a fine black pen and write the correction in the margin, not too close to the edge of the page.

- Remember to note the journal title, article number, and your name when sending your response via e-mail or fax.

- Check the metadata sheet to make sure that the header information, especially author names and the corresponding affiliations are correctly shown.

- Check the questions that may have arisen during copy editing and insert your answers/ corrections.

- Check that the text is complete and that all figures, tables and their legends are included. Also check the accuracy of special characters, equations, and electronic supplementary material if applicable. If necessary refer to the Edited manuscript.

- The publication of inaccurate data such as dosages and units can have serious consequences. Please take particular care that all such details are correct.

- Please do not make changes that involve only matters of style. We have generally introduced forms that follow the journal's style.

Substantial changes in content, e.g., new results, corrected values, title and authorship are not allowed without the approval of the responsible editor. In such a case, please contact the Editorial Office and return his/her consent together with the proof.

- If we do not receive your corrections within $\mathbf{4 8}$ hours, we will send you a reminder.

- Your article will be published Online First approximately one week after receipt of your corrected proofs. This is the official first publication citable with the DOI. Further changes are, therefore, not possible.

- The printed version will follow in a forthcoming issue.

\section{Please note}

After online publication, subscribers (personal/institutional) to this journal will have access to the complete article via the DOI using the URL: http://dx.doi.org/[DOI].

If you would like to know when your article has been published online, take advantage of our free alert service. For registration and further information go to: http://www.link.springer.com.

Due to the electronic nature of the procedure, the manuscript and the original figures will only be returned to you on special request. When you return your corrections, please inform us if you would like to have these documents returned. 


\section{Metadata of the article that will be visualized in OnlineFirst}

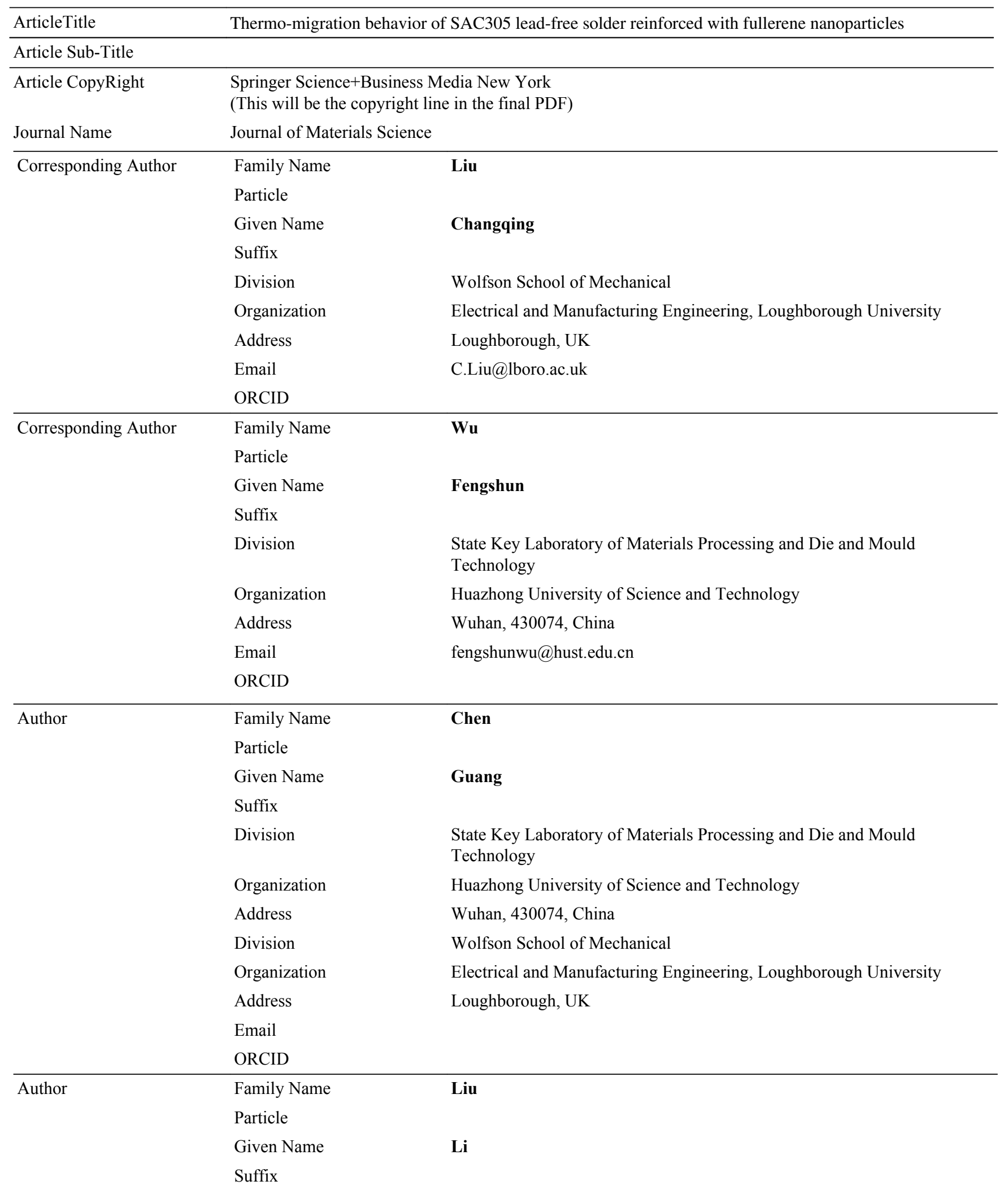




\begin{tabular}{|c|c|c|}
\hline & Division & Wolfson School of Mechanical \\
\hline & Organization & Electrical and Manufacturing Engineering, Loughborough University \\
\hline & Address & Loughborough, UK \\
\hline & Email & \\
\hline & ORCID & \\
\hline \multirow[t]{9}{*}{ Author } & Family Name & Du \\
\hline & Particle & \\
\hline & Given Name & Juan \\
\hline & Suffix & \\
\hline & Division & Wolfson School of Mechanical \\
\hline & Organization & Electrical and Manufacturing Engineering, Loughborough University \\
\hline & Address & Loughborough, UK \\
\hline & Email & \\
\hline & ORCID & \\
\hline \multirow[t]{9}{*}{ Author } & Family Name & Silberschmidt \\
\hline & Particle & \\
\hline & Given Name & Vadim V. \\
\hline & Suffix & \\
\hline & Division & Wolfson School of Mechanical \\
\hline & Organization & Electrical and Manufacturing Engineering, Loughborough University \\
\hline & Address & Loughborough, UK \\
\hline & Email & \\
\hline & ORCID & \\
\hline \multirow[t]{10}{*}{ Author } & Family Name & Chan \\
\hline & Particle & \\
\hline & Given Name & Y.C. \\
\hline & Suffix & \\
\hline & Division & Department of Electronic Engineering \\
\hline & Organization & City University of Hong Kong \\
\hline & Address & Tat Chee Avenue, Kowloon Tong, Hong Kong \\
\hline & Email & \\
\hline & ORCID & \\
\hline & Received & 18 April 2016 \\
\hline \multirow[t]{2}{*}{ Schedule } & Revised & \\
\hline & Accepted & 18 July 2016 \\
\hline Abstract & \multicolumn{2}{|c|}{ 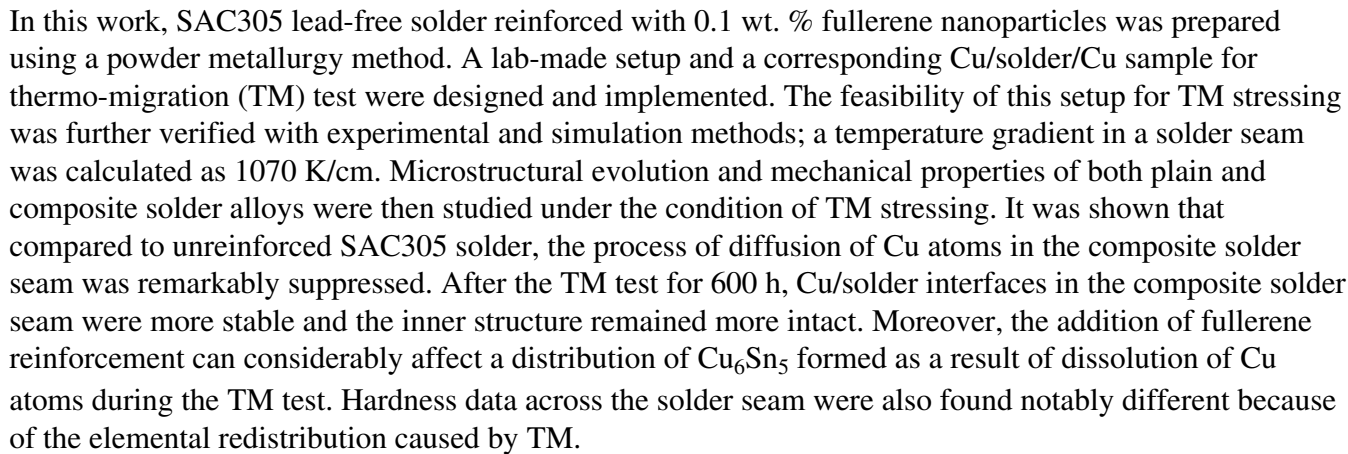 } \\
\hline
\end{tabular}


2D materials

_ab initio calculations

_additive manufacturing

_adhesion

_adsorption

_aerogels

_AFM

_alloys

_amorphous materials

_annealing

_antifouling materials

_atomic-layer deposition (ALD)

- atomistic modeling

batteries

batteries, lithium

_batteries, magnesium

_batteries, sodium

BCC metals

_bio-inspired materials

_biomass conversion

_biomaterials

_biomechanics

biomimetic

_black phosphorus

_blends

_brazing

_calcification

-capacitors

_carbon fiber

_carbon nanotube

casting

_catalysts or catalysis

- cellular materials

_cellulose

ceramics

_characterization methods

_chemical vapor deposition (CVD)

$\mathrm{CO}_{2}$ sequestration

_coatings

_colloids or bio-colloids

_composite materials

_computational materials science

_computer modeling

_computer simulation

_conducting polymers

_corrosion and oxidation

_corrosion protection

_crystal plasticity

_crystallization

_curing

_data analytics

_defects

deformation

_deposition

_dielectrics

_diffraction, electron

diffraction, neutron

_diffraction, X-ray (XRD)

diffusion

diodes

_dislocation dynamics

dislocations

_drug delivery

_dye-sensitized solar cells (DSSCs)

_dysfunctional materials
EBSD

_elastic properties

electrical properties

-electrocatalysis

_electrochemistry

_electrode materials

_electron-beam melting

_electronic materials

_electronic properties

_electrospinning

_embrittlement

_energy harvesting

_epitactic or epitaxial growth

fatigue

FCC metals

ferroelectrics

FGMs

fibers or fiber technology

_food colloids

fracture

_fuel cells

functional anisotropy

_functional materials

_gas-phase transport

_gelation

geocomposites

_glass

_grain boundaries

_grain boundary engineering

_graphene

_graphitic carbon

hardness

HCP metals

healing

- heat treatment

hierarchical materials

-high entropy alloys

_high pressure torsion

_high throughput testing

_hot isostatic pressing

_hydrogels

_hydrogen storage or production

hydrolysis

_II-VI compounds

_III-V compounds

_imaging

In situ or operando

- infrared spectroscopy

- intercalation

interfaces

intermetallics

-ionomers

- kinetics

laminates

_laser processing

latticed effects

_layered materials

_light alloys

light-emitting diodes

_liquid crystals

_lithography

machining

macro defects

_magnetic materials or properties

magnetic ordering materials design

_materials for demanding environments

materials for energy

_mechanical properties

membranes

mesoporous materials

metal-insulator transition

_metal/organic frameworks (MOFs)

_metallic glasses

_metals

_metamaterials

_microanalysis

_microstructure

- minerals or mineralization

_molding

_molecular dynamics

- molecular simulation

_molecular-beam epitaxy (MBE)

_morphology

_multiferroics

_multilayers

_nanocomposites

_nanofunctionality

_nanoindentation

_nanolithography

_nanomaterials

_nanomedicines

_nanoporous materials

natural materials

-NDT

-NMR

_nuclear materials

_nucleation

_omniphobic materials

_optical materials and properties

_organic electronics

_organic solar-cell materials

_permselective materials

perovskite

_perovskite solar cell (PSCs)

_phase diagrams

_phase transformations

_phase-change materials (PCMs)

_phase-field modeling

phosphors

photocatalysis

_photonic materials

photoreactive materials

phototherapeutics

photovoltaics (solar cells)

_piezoelectric materials

_plasma deposition

_plasmonic materials

plating

_polymers

_porous materials

_powder technology

pyroelectrics

_quasicrystals

_radiation damage

radiation effects

_rapidly solidified materials

_redox flow batteries

_regenerative medicine resorbable materials

_responsive materials

rheology

sapphire $/ \mathrm{Al}_{2} \mathrm{O}_{3}$

scaffolds

_scanned-probe microcopy

selective laser melting

self-assembly

_self-healing materials

_SEM

_semiconductors

_sensing and sensors

- severe plastic deformation

_shape memory materials

_silicones

_ singlet-exciton fission

_sintering

_small volume testing

smart materials

_sodium-sulphur batteries

_soft interfaces

_soft matter

_sol-gel preparation

solidification

_solvothermal/hydrothermal

_spectroscopy (XPS)

spin glass

_spintronics

_sputter deposition

STM

superalloys

_supercapacitors

_superconductors

_superelasticity

_superhydrophobic

surface treatments

_surfaces

surfactants

technical textiles

TEM

texture

theranostics

- thermal barrier coatings

-thermal properties

- thermodynamics

-thermoelectrics

thin-film or thick-film coatings

- $\mathrm{TiO}_{2}$ rutile, anatase or brookite

_tissue engineering

tomography

_topological insulators

_transparent conductors

-transport mechanisms

- tribology

twinning

- TWIP steels

- two-photon adsorption

_UFG materials

_viscoelasticity

_viscosity

_water-splitting

_wear

-wood

XPS

zeolite 
Received: 18 April 2016

Accepted: 18 July 2016

(C) Springer Science+Business Media New York 2016

\footnotetext{
'State Key Laboratory of Materials Processing and Die and Mould Technology, Huazhong University of Science and Technology, Wuhan 430074, China

${ }^{2}$ Wolfson School of Mechanical, Electrical and Manufacturing Engineering, Loughborough University, Loughborough, UK ${ }^{3}$ Department of Electronic Engineering, City University of Hong Kong, Tat Chee Avenue, Kowloon Tong, Hong Kong
}

\begin{abstract}
In this work, SAC305 lead-free solder reinforced with 0.1 wt. \% fullerene nanoparticles was prepared using a powder metallurgy method. A lab-made setup and a corresponding $\mathrm{Cu}$ /solder/ $\mathrm{Cu}$ sample for thermo-migration (TM) test were designed and implemented. The feasibility of this setup for TM stressing was further verified with experimental and simulation methods; a temperature gradient in a solder seam was calculated as $1070 \mathrm{~K} / \mathrm{cm}$. Microstructural evolution and mechanical properties of both plain and composite solder alloys were then studied under the condition of TM stressing. It was shown that compared to unreinforced SAC305 solder, the process of diffusion of $\mathrm{Cu}$ atoms in the composite solder seam was remarkably suppressed. After the TM test for $600 \mathrm{~h}, \mathrm{Cu}$ /solder interfaces in the composite solder seam were more stable and the inner structure remained more intact. Moreover, the addition of fullerene reinforcement can considerably affect a distribution of $\mathrm{Cu}_{6} \mathrm{Sn}_{5}$ formed as a result of dissolution of $\mathrm{Cu}$ atoms during the TM test. Hardness data across the solder seam were also found notably different because of the elemental redistribution caused by TM.
\end{abstract}

\section{Introduction}

SAC305 (wt. \%) lead-free solder is widely used in electronic interconnections, thanks to its outstanding mechanical properties and good reliability under service conditions [1-3]. However, with fast developments in miniaturization and integration density in high-density electronic packages, electro- and thermo- migration (TM) failures induced by a high current density and large thermal gradients have become a main problem which would threaten the reliability of SAC305 solder interconnections [4-8]. The microstructural and mechanical evolution together with failure modes of solder joints under TM and EM stressing were also reported in previous studies [9-14]. Abdulhamid et al. [9] comprehensively

Address correspondence to E-mail: C.Liu@lboro.ac.uk; fengshunwu@hust.edu.cn

\begin{tabular}{|l|lll|}
\hline Journal : 10853 - Large 10853 & Dispatch : 21-7-2016 & Pages : 15 \\
Article No. : 234 & $\square$ LE & $\square$ TYPESET \\
MS Code : JMSC-D-16-02130 & $\checkmark$ CP & $\square$ DISK \\
\hline
\end{tabular}


investigated the damage mechanics of $95.5 \mathrm{Sn} 4 \mathrm{Ag}$ $0.5 \mathrm{Cu}$ (SAC405) lead-free solder joints under TM stressing. After $1156 \mathrm{~h}$ TM stressing, they found that the $\mathrm{Cu}$ concentration in cold side is significantly higher than in hot side, while vacancy migration and Sn grain coarsening are in the opposing direction. In order to deeply understand the TM process, a fully coupled thermo-mechanical model is introduced by Basaran et al. [10]; the TM induced strength degradation and grain coarsening effects were both analyzed. Further, they also comparatively studied the migration mechanism in solder joints under EM and $\mathrm{EM} / \mathrm{TM}$ stressing [12].It was also reported that $\mathrm{TM}$ is more likely to lead to failures of solder joints in some cases [15]. Therefore, with the trend of decreasing interconnection height, lead-free solder interconnections will face with reliability challenges related to electro-migration (EM) and in particular, TM.

According to previous studies, mechanical properties and solderability of existing lead-free solders could be improved by adding some foreign reinforcement (including metals, ceramics, and carbonbased materials) into a solder matrix to prepare a composite solder [16-21]. In addition, some researchers also attempted to investigate an effect of foreign reinforcement on EM in solder joints; it was reported that a suitable type and an appropriate amount of reinforcement added showed a positive effect on suppressing EM in solder joints [22-27]. However, to date, a systematic study of TM behavior of composite solder interconnections containing foreign reinforcement under large temperature gradient is still lacking.

As a zero-dimensional carbon-based nanomaterial, a unique molecular structure of fullerene determines its physical stability, low density as well as its excellent electrical, thermal, and mechanical properties [28-32]. Hence, it was usually used as reinforcing phase in preparing polymer- and metal-based composite materials [33, 34]. Chernogorova et al. [33] reported that tensile strength and microhardness of an aluminum/C60 composite alloy were significantly improved with the addition of $\mathrm{C} 60$ reinforcement. Watanabe et al. [34] fabricated an Mg-Al-Zn/fullerene (C60) composite alloy with a powder metallurgy method; the produced material demonstrated superelasticity under $548 \mathrm{~K}$ (with $256 \%$ elongation). Our research group also prepared a SAC305/fullerene (mixture of C60 and C70) composite solder with a powder metallurgy method; the influence of fullerene on microstructure and mechanical properties on SAC solder joints were also systematically studied. It was found that addition of a proper amount of fullerene was effective in microstructural refinement and improvement in mechanical properties of solder joints [35]. To study further the effect of fullerene reinforcement on thermo-migration behavior of solder joints, in this paper, a SAC/fullerene composite solder reinforced with nano-sized fullerene particles was similarly prepared with the powder metallurgy method. $\mathrm{Cu} /$ Solder/Cu-structured interconnections were then formed for subsequent thermo-migration tests. It is widely reported that TM in Sn-based solder joints can be triggered when a temperature gradient and an environmental temperature reach at least $1000 \mathrm{~K} / \mathrm{cm}$ and $100{ }^{\circ} \mathrm{C}$, respectively [36]. Therefore, for TM tests, to achieve a large enough thermal gradient and environmental temperature without involving EM factor, a TM setup based on a heating plate with constant temperature and a Peltier thermoelectric cooler was designed and prepared. Feasibility of the as-designed setup and corresponding samples was also further verified in this work.

After progressively prolonged TM tests, evolution of interfacial intermetallics (IMCs) at the hot and cold ends and microstructure at the center of both plain and composite solder seams were comparatively studied. Additionally, the dissolution of $\mathrm{Cu}$ atoms into the solder seams was quantitatively evaluated. Moreover, the change in mechanical properties of the solder seams as a result of redistribution of elements during the TM test was also investigated. The findings in this work could promote our understanding of the impact of thermal gradient and environmental temperature on reliability of composite solder joints without the effect of current. It can also facilitate future studies on mitigating failures in solder joints induced by thermo-migration.

\section{Experimental}

Preparation of composite solder

SAC305 (wt. \%) lead-free solder powder (with diameter of $25-45 \mu \mathrm{m}$, Beijing Compo, China) and a mixture of fullerene nanoparticles (approximately $80 \%$ C60 and $20 \%$ C70 with an average diameter of $30 \mathrm{~nm}$, JCNANO Materials Tech, China) were utilized as original materials. For preparation of 
Figure 1 Schematic diagram of TM setup (a), TM samples (b), and thermocouple positions (c). (a)

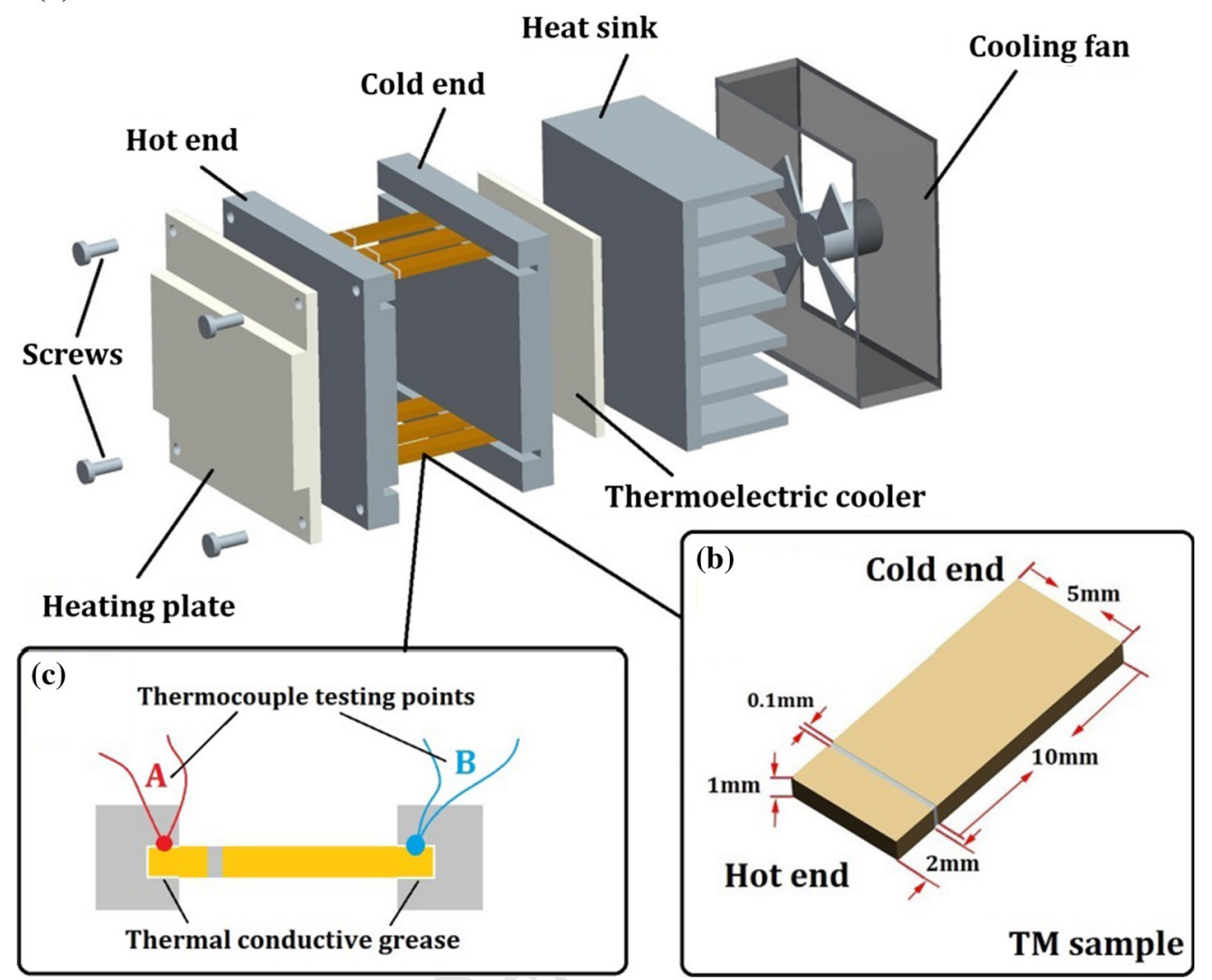

composite solder, the preweighted solder powder (99.9 wt \%) and fullerene particles (0.1 wt. \%) were homogenously blended in a planetary ball mill for $20 \mathrm{~h}$. The mixed powder was then uniaxially compacted into solder billets ( $24 \mathrm{~mm} \times 8 \mathrm{~mm} \times 3 \mathrm{~mm}$ ). These compacted solder billets were then sintered at $180{ }^{\circ} \mathrm{C}$ for $3 \mathrm{~h}$ in a vacuum sintering furnace before rolling into solder foils (with thickness of $100 \mu \mathrm{m}$ ) to prepare TM samples.

\section{Design and preparation of TM setup and sample}

To achieve a large enough thermal gradient across solder seams, a lab-made TM test setup was designed and prepared (as shown in Fig. 1a). The TM setup consisted of a constant-temperature heating plate with a temperature of $250 \pm 5^{\circ} \mathrm{C}$ as the heat resource and a Peltier thermoelectric cooler for cooling. A stable initial temperature $\left(0 \pm 2{ }^{\circ} \mathrm{C}\right)$ of the thermoelectric cooler was guaranteed by a temperature controller, while a heat sink and cooling fan were used to ensure its proper functioning during current stressing. The heating and cooling components were fixed on corresponding $\mathrm{Cu}$ bases with grooves (they were also the hot and cold sides in the TM tests). The spacing between two $\mathrm{Cu}$ bases was kept as $10 \mathrm{~mm}$, while rectangular grooves with depth of $1 \mathrm{~mm}$ for placing TM samples were also produced on both hot and cold $\mathrm{Cu}$ bases with wire-electrode cutting. According to the difference of coefficients of heat conduction for different materials, the sample for TM was designed as an asymmetrical structure with a shorter hot end $(2 \mathrm{~mm})$ and a longer cold end $(10 \mathrm{~mm}) ; \mathrm{a} \mathrm{Cu}$ plate (with thickness of $1 \mathrm{~mm}$ and width of $5 \mathrm{~mm}$ ) was used as substrate material for both hot and cold sides of the sample. For sample preparation, end surfaces of the $\mathrm{Cu}$ substrates of both sides were well polished before soldering. A solder foil with dimensions of $5 \mathrm{~mm} \times 1 \mathrm{~mm} \times 0.1 \mathrm{~mm}$ was then clamped between two $\mathrm{Cu}$ substrates; finally, the clamped $\mathrm{Cu}$ substrates and the solder foil together with the clamp were placed in a reflow oven to prepare a sample of $\mathrm{Cu} /$ solder/ $\mathrm{Cu}$ sandwich-like structure. The width of solder seams in reflowed solder samples remained similar to the thickness of the initial solder foils (namely, $100 \mu \mathrm{m}$ ); schematic diagram of a reflowed sample is shown in Fig. 1b. For

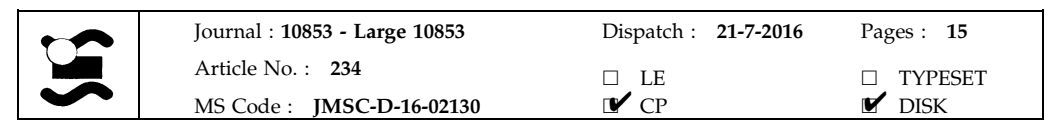


the TM tests, the hot and cold ends of the prepared sample were correspondingly embedded in the above-mentioned grooves on both hot and cold $\mathrm{Cu}$ bases; the embedded depth was approximately $1 \mathrm{~mm}$. To ensure good thermal conduction, thermal silicone grease was applied on each contact surface between different parts in the tests. In order to know the levels of temperature gradient and environmental temperature in the solder seam, experimental measurements and finite-element modeling were employed to evaluate the feasibility of the TM setup and the samples. A finite-element model was built with ANSYS 15.0 according to the actual dimensions of the setup and sample. To get good modeling results for a temperature distribution across the solder seam, thermocouples were first utilized to obtain the real temperature at points $\mathrm{A}$ and $\mathrm{B}$ during current stressing (the distances from $\mathrm{A}$ and $\mathrm{B}$ to the solder seam were $1 \mathrm{~mm}$ and $9 \mathrm{~mm}$, respectively, as illustrated in Fig. 1c). The obtained average temperatures for points A and B were recorded when the temperature difference reached a balance; the recorded data were then set as the loading temperatures of the two ends for the subsequent modeling.

\section{TM tests and characterization}

In the TM tests, five samples for each kind of solder (plain and composite) were tested to satisfy different testing purposes. Specifically, microstructural evolution of one selected sample for each kind of solder was continuously observed a using scanning electron microscope (SEM QURTA 200) every $200 \mathrm{~h}$; the total stressing time of the TM tests was designed as $600 \mathrm{~h}$. The rest of samples that experienced the same TM stressing process were used for mechanical and compositional analysis. A focused ion beam (FIB) system was employed to study the distribution of $\mathrm{Cu}$ Sn IMCs within a subsurface layer of the studied solder seams, while features of the inner structure were studied with an X-ray Micro-CT scanner (Metris XT H 160Xi) before and after the TM tests. Mechanical properties of the solder seams before and after the TM tests were also evaluated with a nanoindenter (Hysitron Ti750) at a constant load rate of $10 \mathrm{mN}$ and a dwell time of $5 \mathrm{~s}$. To know the difference in mechanical properties in different areas, in nanoindentation tests, each solder seam was evenly divided into three areas, denoted as A, B, and C at different positions between cold and hot ends. Five randomly selected locations for each area were tested to ensure reliability of the test results. In addition, to evaluate quantitatively the process of dissolution of $\mathrm{Cu}$ atoms into the solder seams under a large temperature gradient, the seams were cut off from the TM samples after different TM stressing times. After that, residual $\mathrm{Cu}$ at the surface of the solder seams was removed by fine polishing. The treated solder seams were then ultrasonically dissolved in aqua regia solution for elemental analysis using an inductively coupled plasma optical emission spectroscopy (ICP-OES, Varian-720) with test precision at PPM level.

\section{Results and discussion}

Feasibility evaluation of TM setup and sample

Evolution of measured temperature at points A and B with the stressing time in the TM test is shown in Fig. 2. It can be seen from the curves that the temperature saw a continual increase at the hot end after current stressing, while the temperature of the cold end demonstrated a small decrease first and then increased gradually; after approximately $7 \mathrm{~min}$ of the stressing, the temperature difference between the hot and cold ends reached equilibrium. During this stable stage, the average temperatures of the hot (point A) and cold (point B) ends were measured as 206.7 and $40.3{ }^{\circ} \mathrm{C}$, respectively.

The temperature data obtained from the TM sample were used as original temperature parameter for finite-element modeling (FEM). The calculated temperature distributions in the TM setup and the solder seam are presented in Fig. 3. According to the simulation results, the temperature of hot side of the solder seam reached $181.4^{\circ} \mathrm{C}$, while the temperature of the cold side could reach $170.7^{\circ} \mathrm{C}$. In such a case, the temperature difference in the solder seam could achieve $1070 \mathrm{~K} / \mathrm{cm}$, since the width of the solder seam was $100 \mu \mathrm{m}$; the average environmental temperature at the solder seam was approximately $176{ }^{\circ} \mathrm{C}$. According to previous studies [37], TM in lead-free solders can be triggered when the temperature gradient and the environmental temperature reach at least $1000 \mathrm{~K} / \mathrm{cm}$ and $100{ }^{\circ} \mathrm{C}$, respectively. In this work, it is clear that the obtained levels of temperature gradient and environmental temperature in the solder seam properly meet these requirements. 
Figure 2 Evolution of temperature at points $\mathrm{A}$ and $\mathrm{B}$ with stressing time.

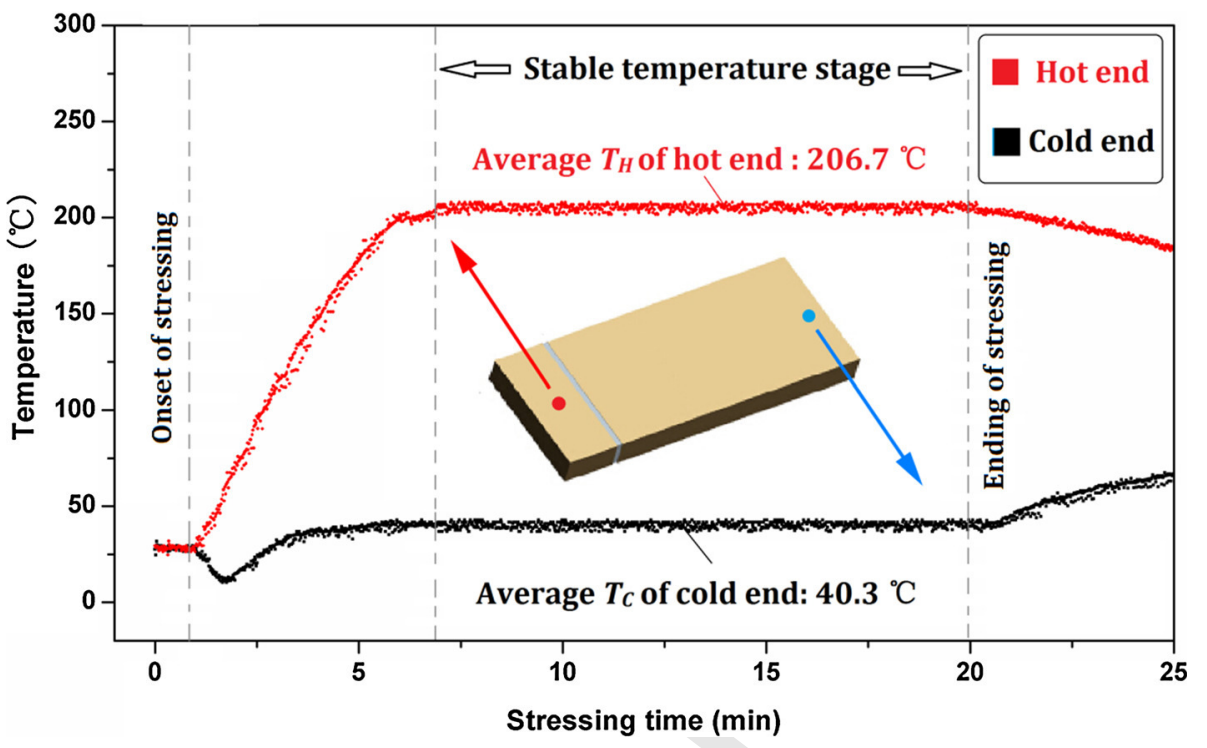

Thus, the TM setup and the produced sample are feasible for the TM tests.

\section{Microstructural evolution}

The microstructures of both plain and composite solder seams after different TM stressing times are shown in Figs. 4 and 5; the variation in thickness of interfacial $\mathrm{Sn}-\mathrm{Cu}$ IMCs during TM testing is plotted in Fig. 6. It can be found from images of the solder seam before the TM test that $\beta-S n, \mathrm{Ag}_{3} \mathrm{Sn}$ IMC and $\mathrm{Cu}_{6} \mathrm{Sn}_{5}$ IMC were present in both kinds of solder seams. It is worth noting that the sizes of $\beta$-Sn phase and $\mathrm{Ag}_{3} \mathrm{Sn}$ IMCs in the fullerene-reinforced composite solder seam were found to be apparently smaller than that in the plain SAC305 solder seam. This phenomenon can be explained in the following way: the added foreign reinforcement provided more nucleation sites during the solidification process; they also could impede the growth of grains by hindering atomic diffusion [35]. With the TM stressing time increasing, large quantities of bulky Cu-Sn IMCs can be found in both plain and composite solder seams; these $\mathrm{Cu}-\mathrm{Sn}$ IMC are a mixture of the initial $\mathrm{Cu}_{6} \mathrm{Sn}_{5}$ in the SAC305 solder and the newly formed $\mathrm{Cu}_{6} \mathrm{Sn}_{5}$ as a result of dissolution and migration of $\mathrm{Cu}$ atoms coming from the $\mathrm{Cu}$ substrates. However, it is apparent that the size and quantity of these $\mathrm{Cu}-\mathrm{Sn}$ IMCs in the plain SAC305 solder seam were larger than those in the composite solder seam, as shown in Figs. $4 d, g$, j and 5d, g, j. For the unreinforced SAC305 sample, it was found that $\mathrm{Cu}-\mathrm{Sn}$ IMCs formed first at the hot end and the central position of the solder seam after $200 \mathrm{~h}$ stressing. With the stressing time increasing, the amount of $\mathrm{Cu}-\mathrm{Sn}$ IMCs continued to grow, and these oval-shaped IMCs were also gradually distributed in the whole solder seam (after $400 \mathrm{~h}$ stressing). After $600 \mathrm{~h} \mathrm{TM}$ stressing, most of the $\mathrm{Cu}$ Sn IMCs were observed to locate at the central position and the cold end of the solder seam. By contrast, after $200 \mathrm{~h}$ TM stressing, although the formation and location of $\mathrm{Cu}-\mathrm{Sn}$ IMCs in the fullerene-reinforced solder seam are similar to those in the plain solder seam, the size of these newly formed IMCs was clearly smaller when compared to their counterparts in the unreinforced SAC305 solder seam after the same stressing time. In addition, there is also a big difference in microstructures for two solder seams after $400 \mathrm{~h}$ and $600 \mathrm{~h}$ of TM stressing. Specifically, $\mathrm{Cu}-\mathrm{Sn}$ IMCs formed as result of $\mathrm{Cu}$ diffusion were found in both solder seams at the early stressing stage (0-200 h); however, compared to the obvious migration of $\mathrm{Cu}-\mathrm{Sn}$ IMCs in the plain solder seam, the changes of location of these IMCs in the composite solder seam were not that evident over time. Furthermore, most of IMCs in the composite solder seam were still located at the hot end and the central position after $400 \mathrm{~h}$ and $600 \mathrm{~h}$ stressing; only a small part of these IMCs were found at the position closed to the cold end, since the distribution of reinforcement added in the composite solder seam might not relatively uniform after reflow process.

In addition to the difference in microstructural evolution for two solder seams, the growth

\begin{tabular}{|llll|}
\hline Journal : 10853 - Large 10853 & Dispatch : 21-7-2016 & Pages : $\mathbf{1 5}$ \\
& Article No. : $\mathbf{2 3 4}$ & $\square$ LE & $\square$ TYPESET \\
MS Code : JMSC-D-16-02130 & $\checkmark$ CP & $\square$ DISK \\
\hline
\end{tabular}




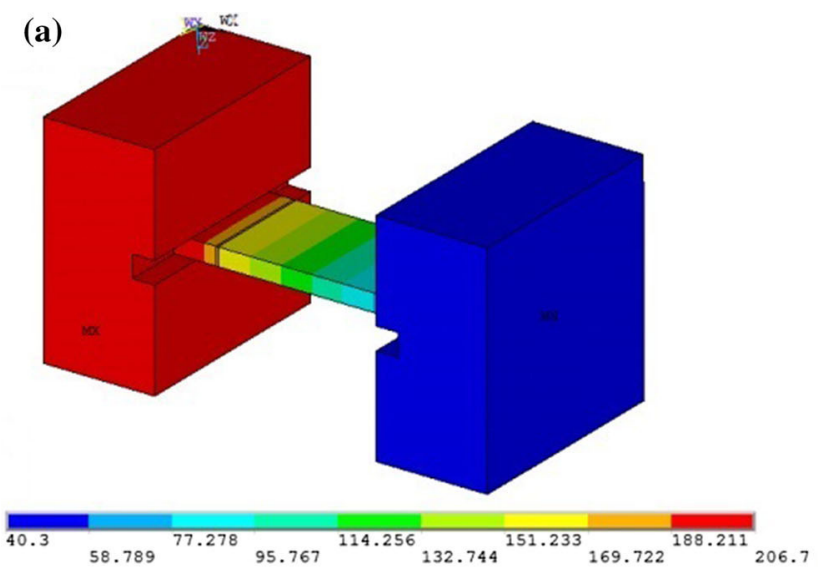

(b)

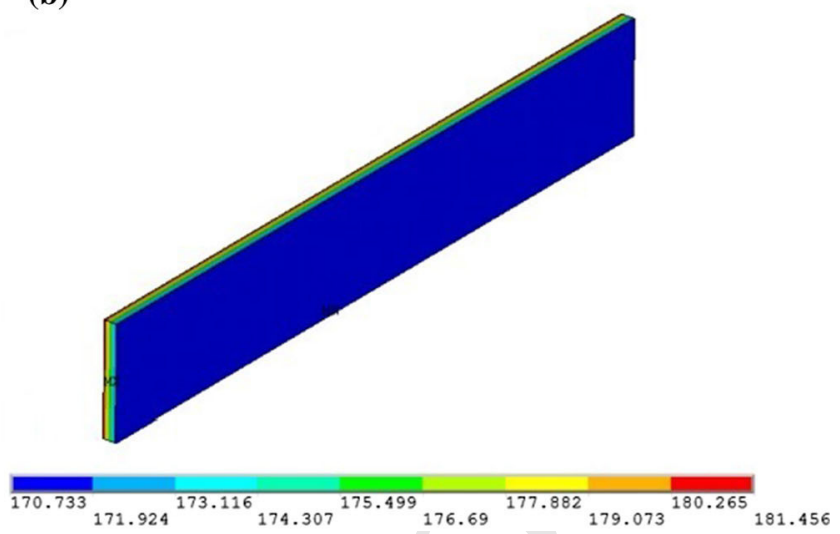

Figure 3 Temperature distributions in TM setup (a) and solder seam (b).

characteristics of interfacial IMCs of two types of samples were also different during TM stressing. For the plain solder seam, as shown in Fig. 4, the thickness of interfacial IMCs at the cold end obviously increased with the stressing time. The measured data for thickness shown in Fig. 6a also confirmed this trend; the thickness of interfacial IMCs at the cold end increased from the initial $2.12 \mu \mathrm{m}$ to $8.96 \mu \mathrm{m}$ after $600 \mathrm{~h}$ stressing, i.e., approximately $323 \%$. In addition, the morphological evolution of interfacial IMC at hot end also worth noting. It can also be found from Fig. 4 that the thickness of interfacial IMCs at the hot end similarly showed a gradually increasing trend during the first $400 \mathrm{~h}$ of stressing; the thickness increased from $2.51 \mu \mathrm{m}$ to $3.36 \mu \mathrm{m}$, as shown in Fig. 6a. However, the thickness variation of interfacial IMC at hot end was not that pronounced compared to that for the cold end. Further, some Kirkendall voids were found in interfacial IMCs at the hot end after $400 \mathrm{~h}$ of TM stressing (see Fig. 4i). After $600 \mathrm{~h}$ of stressing, it can be seen that the initial interface at the hot end was damaged; only a very thin layer of IMC retained on the $\mathrm{Cu}$ substrate. The interfacial damage at the hot end can be attributed to considerable diffusion and migration of $\mathrm{Cu}$ atoms from the substrate into the solder seam during the TM stressing process; this interfacial damage also further blocked diffusion pathways for $\mathrm{Cu}$ atoms. As to the cold end, some granular $\mathrm{Ag}_{3} \mathrm{Sn}$ phase with light gray color was also observed in $\mathrm{Cu}_{6} \mathrm{Sn}_{5}$ interfacial IMC after $600 \mathrm{~h}$ of TM stressing. The observed formation, migration, and location of $\mathrm{Cu}-\mathrm{Sn}$ and $\mathrm{Sn}-$ Ag IMCs in the SAC305 solder seam during TM stressing illuminate that both $\mathrm{Cu}$ and $\mathrm{Ag}$ atoms migrate from the hot end to the cold one under the large temperature gradient; this finding in the present study is consistent with the current research results obtained by other researchers [15, 38].

In contrast, the growth of interfacial IMCs between the composite solder seam and the $\mathrm{Cu}$ substrates was mitigated considerably during TM stressing. Specifically, the thickness of interfacial IMCs at the cold end similarly showed an increase with the stressing time, from initial 1.86 to $4.86 \mu \mathrm{m}$ after $600 \mathrm{~h}$ (Fig. 6b). The thickness increment for interfacial IMC at the cold end was approximately $161 \%$, significantly less than that in the plain SAC305 solder seam. In addition, no $\mathrm{Ag}_{3} \mathrm{Sn}$ phase was found in interfacial IMCs at the cold end after $400 \mathrm{~h}$ or $600 \mathrm{~h}$ of TM stressing. For the hot end, the thickness of interfacial IMCs also increased with the stressing time, from initial 2.14 to $3.52 \mu \mathrm{m}$ after $600 \mathrm{~h}$. However, in contrast to serious damage happened at the hot interface in the plain SAC305 solder seam, morphology of interfacial IMCs at the hot end in the composite solder seam remained intact even after $600 \mathrm{~h}$ stressing, except that only a few of Kirkendall voids were found in this area. Thus, it is believed that incorporation of fullerene reinforcement inhibited the dissolution process of the $\mathrm{Cu}$ substrate, formation, and migration of Cu-Sn IMCs as well as the growth of interfacial IMCs. Based on the microstructural comparison between the plain and composite solder seams after TM stressing, the retardation of growth and migration of IMCs in the solder seam can be explained as follows. Fullerene is a nonreactive, noncoarsening material, when appearing in grain boundaries; present fullerene might hinder the migration of atoms

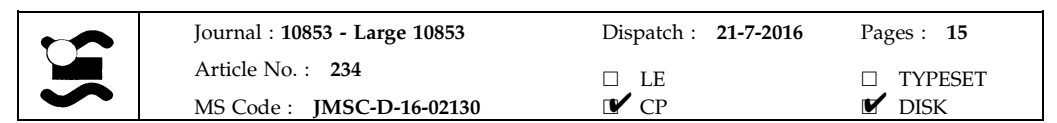



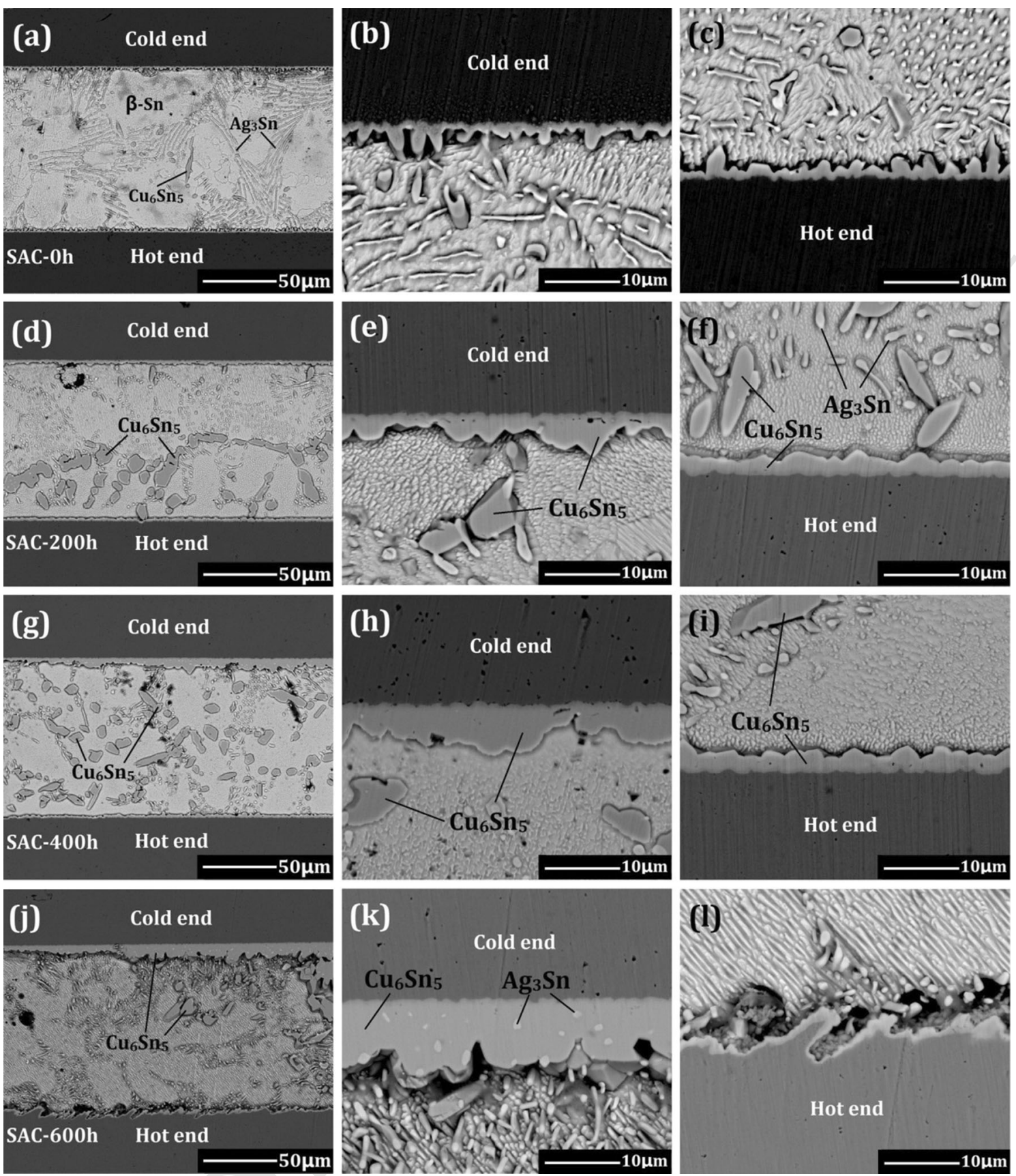

Figure 4 Microstructural evolution of SAC305 solder seam under temperature gradient of $1072 \mathrm{~K} / \mathrm{cm}$ : a-c initial; d-f 200 h; $\mathbf{g}-\mathbf{i} 400 \mathrm{~h}$; j-1 $600 \mathrm{~h}$.

420 which could otherwise accelerate the process of IMC 421 formation. Thus, the relationship between the 422 growth rates for different crystal orientations of 423 IMCs changed, leading to restrictions on growth and 424 migration of IMCs. It is also widely believed that the 425 diffusion coefficient of $\mathrm{Cu}$ atoms in the $\mathrm{Sn}$ matrix is 426 relatively large [39]. Thus, combined diffusion 427 between $\mathrm{Cu}$ and $\mathrm{Sn}$ atoms determined the growth of the interfacial Cu-Sn IMC phase at the solder/copper interface. According to our previous study on location of fullerene added in the solder matrix [35], it is supposed that some fullerene reinforcement stuck around the $\mathrm{Cu}-\mathrm{Sn}$ phases, acting as barriers for diffusion of $\mathrm{Sn}$ to the $\mathrm{Cu}$ substrate or even obstructing formation of $\mathrm{Cu}_{6} \mathrm{Sn}_{5}$, inhibiting the growth of an interfacial IMC layer.

\begin{tabular}{|l|lll}
\hline & Journal : 10853 - Large 10853 & Dispatch : 21-7-2016 & Pages : 15 \\
Article No. : 234 & $\square$ LE & $\square$ TYPESET \\
MS Code : JMSC-D-16-02130 & $\checkmark$ CP & $\longleftarrow$ DISK \\
\hline
\end{tabular}



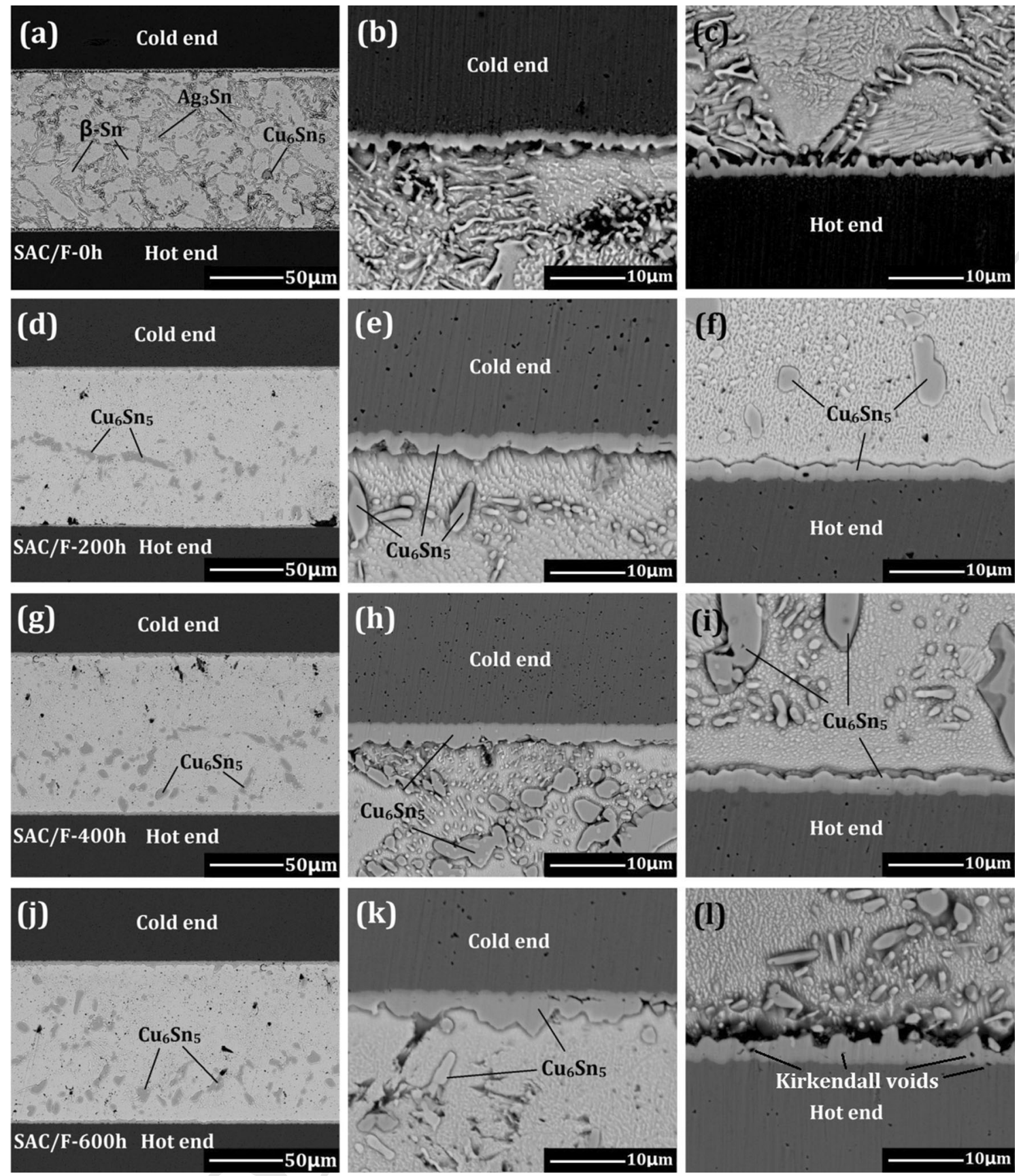

Figure 5 Microstructural evolution of SAC305/F composite solder seam under temperature gradient of $1072 \mathrm{~K} / \mathrm{cm}$ : a-c original; df $200 \mathrm{~h} ; \mathbf{g}-\mathbf{i} 400 \mathrm{~h} ; \mathbf{j}-\mathbf{1} 600 \mathrm{~h}$.

In addition, to understand further the distribution position of Cu-Sn IMCs in a subsurface layer of the solder seam, a dovetail groove with depth of $10 \mu \mathrm{m}$ was prepared on the solder seams after $600 \mathrm{~h}$ of stressing using FIB, and the respective images are shown in Fig. 7. It can be known that after a longterm TM stressing, most of $\mathrm{Cu}-\mathrm{Sn}$ IMCs formed by
$\mathrm{Cu}$ diffusion were found to locate at the central position and the cold end of the plain SAC305 solder seam; the size and location of these IMCs were consistent with the SEM results as shown in Fig. 4. Similarly, the observed location and size of $\mathrm{Cu}-\mathrm{Sn}$ IMCs in the composite solder seam using FIB were almost the same as the results shown in Fig. 5. The
443

\begin{tabular}{|l|lll|}
\hline & Journal : 10853 - Large 10853 & Dispatch : 21-7-2016 & Pages : 15 \\
Article No. : 234 & $\square$ LE & $\square$ TYPESET \\
MS Code : JMSC-D-16-02130 & $\checkmark$ CP & $\square$ DISK \\
\hline
\end{tabular}



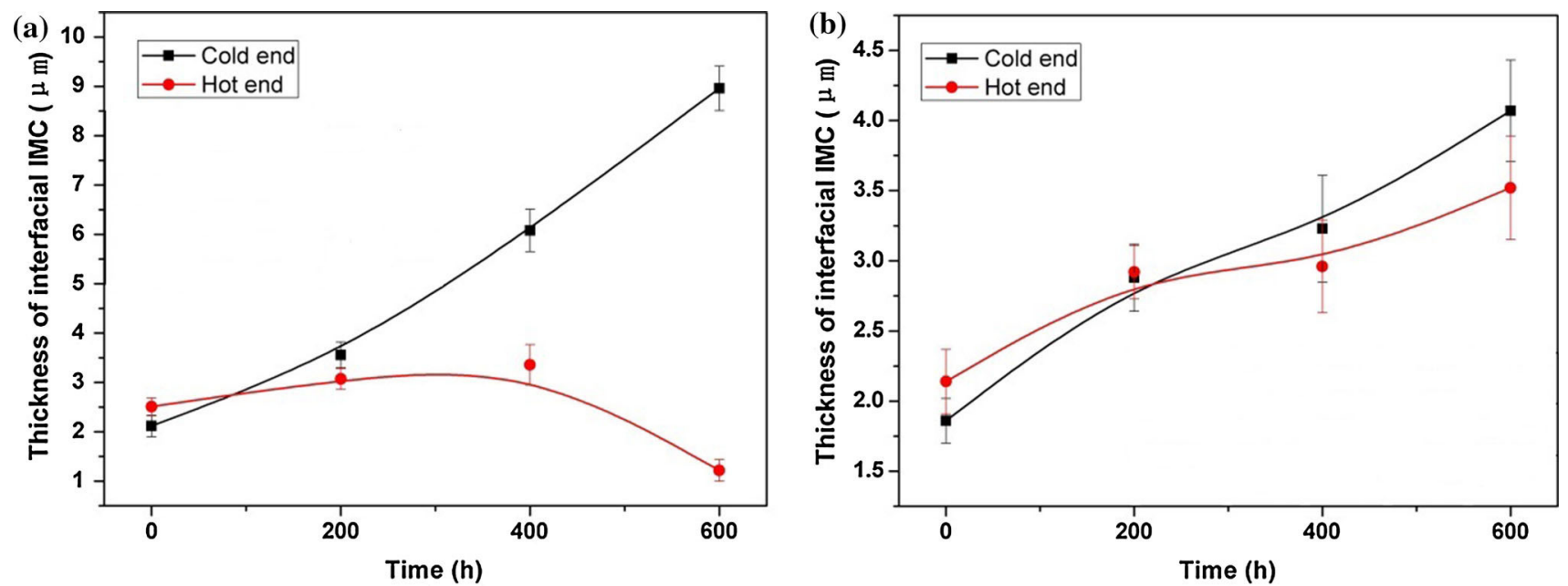

Figure 6 Evolution of thickness of $\mathrm{Cu}-\mathrm{Sn} \mathrm{IMCs}$ at the $\mathrm{Cu} / \mathrm{SAC} 305 / \mathrm{Cu}(\mathbf{a})$ and $\mathrm{Cu} / \mathrm{SAC} 305-\mathrm{F} / \mathrm{Cu}$ (b) with $\mathrm{TM}$ stressing time.

difference of location of $\mathrm{Cu}$-Sn IMCs in the subsurface layer of two kinds for solder seams further indicates that the presence of foreign reinforcement can not only retard the migration of atoms on surface of the solder seam but also mitigate this diffusion in the inner of the solder seam.

To quantitatively measure the effect of addition of fullerene on diffusion of $\mathrm{Cu}$ atoms from the $\mathrm{Cu}$ substrate to the solder seams, the weight percentages of $\mathrm{Cu}$ in the solder seams were analyzed after different TM stressing times using ICP. For the ICP tests, in order to meet the testing requirements (the weight of sample is at least $100 \mathrm{mg}$ ) as well as to understand the $\mathrm{Cu}$ content as precise as possible, four treated samples (cut and polished solder seams; the weight of each solder seam was approximately $38 \mathrm{mg}$ ) were chosen for each kind of solder. The average $\mathrm{Cu}$ content for each solder was used as the testing result for comparative analysis; the ICP results are shown in Fig. 8. Although the cutting and polishing processes can cause errors in measuring the content of $\mathrm{Cu}$ in the solder seams, the obtained results shown in Fig. 8 revealed an obvious difference in the $\mathrm{Cu}$ content in two types of solder seams after different stressing times. Specifically, it increased with the TM stressing time; however, the increase rate in the plain SAC305 solder was much higher seam during whole stressing process than that in the composite solder seam. After $600 \mathrm{~h}$ of stressing, the average $\mathrm{Cu}$ content in the former reached $4.55 \mathrm{wt} \%$, about 9 times higher than its initial value of $0.52 \mathrm{wt} \%$. In contrast, the average $\mathrm{Cu}$ content in the composite solder seam after $600 \mathrm{~h}$ stressing was $2.09 \mathrm{wt} \%$; only about 4 times higher than its initial value of $0.51 \mathrm{wt} \%$. It is also worth noting that the increase rate of $\mathrm{Cu}$ in the plain SAC305 showed a decreasing trend in the interval from $400 \mathrm{~h}$ to $600 \mathrm{~h}$. This phenomenon can also be explained by the fact that the diffusion and migration paths of $\mathrm{Cu}$ atoms at the $\mathrm{Cu}$ /solder interface were damaged due to a long-term TM stressing; this found change in the $\mathrm{Cu}$ content agrees well with the observed results as shown in Fig. 4. To avoid the error caused by the above-described phenomenon, only the data for times below $400 \mathrm{~h}$ were used to calculate the dissolution rate of $\mathrm{Cu}$ atoms during TM stressing. This rate was calculated employing the following formula:

$v=\frac{M\left(w_{2}-w_{1}\right)}{T}$,

where $\mathrm{v}$ is the dissolution rate of $\mathrm{Cu}$ atoms, $M$ is the average weight of the solder seam, $T$ is the stressing time, $w_{1}$ and $w_{2}$ are the weight percentages of $\mathrm{Cu}$ in the solder seams after $0 \mathrm{~h}$ and $400 \mathrm{~h}$ stressing, respectively. After $400 \mathrm{~h}$ stressing, the net increase of $\mathrm{Cu}$ in the SAC305 solder seam was $3.27 \mathrm{wt} \%$; since the weight of the solder seam was $38 \mathrm{mg}, 1.24 \mathrm{mg}$ of $\mathrm{Cu}$ was dissolved into the solder seam during $400 \mathrm{~h}$ of stressing. Due to the fact that the experimental parameters, including the temperature gradient and environmental temperature within the solder seam were relatively stable, the dissolution rate of $\mathrm{Cu}$ atoms form the substrate to the solder seam can thus be calculated as $3.1 \times 10^{-6} \mathrm{~g} / \mathrm{h}$. By comparison, the increment of $\mathrm{Cu}$ content was only $0.488 \mathrm{mg}$ in the composite solder seam after $400 \mathrm{~h}$ stressing; the
483

484

485

486

487

488

489

490

491

492

493

494

495

496

498

499

500

501

502

503

504

505

506

507

508

509

510

511

512

513

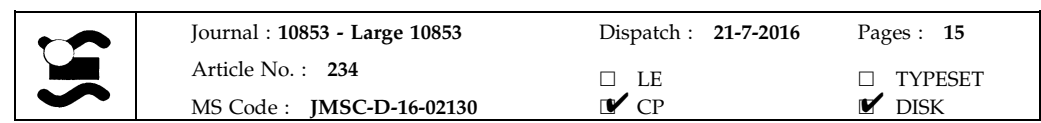



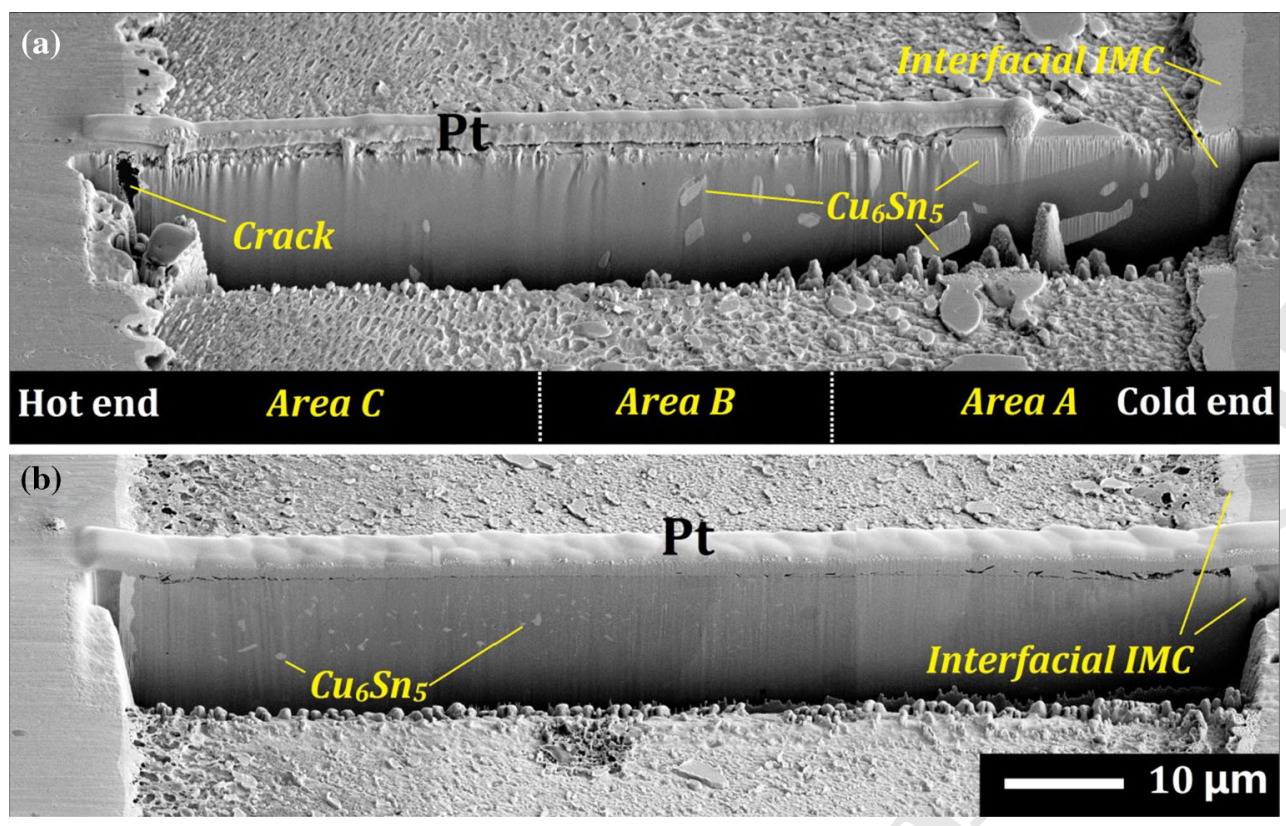

Figure 7 SEM images of FIB-cut trenches on subsurface layer of SAC305 (a) and SAC305/F (b) solder seams.

514 dissolution rate of $\mathrm{Cu}$ atoms was calculated as $5151.22 \times 10^{-6} \mathrm{~g} / \mathrm{h}$, which is only about a half of that in 516 the plain solder seam. The ICP results and the cal517 culated dissolution rates of $\mathrm{Cu}$ atoms clarify that 518 addition of fullerene reinforcement contributed to 519 mitigation of the diffusion from the $\mathrm{Cu}$ substrate into

the solder seam under TM conditions.

To further access the effect of TM on inner structure of the solder seams, MCT nondestructive scanning was employed to analyze the solder seam area; the scanning results are shown in Fig. 9. Apparently, solder seam areas of both types of samples appear rather intact, without apparent defects before TM stressing (see Fig. 9a and c). However, big differences in inner structures were found for two solder seams after $600 \mathrm{~h}$ of TM stressing. Specifically, voids and cracks caused by elemental migration were found at both hot and cold interfaces of the plain SAC305 solder seam; further, large amounts of Cu-Sn IMCs (dark-gray areas) can also be observed at both sides of the solder seam (Fig. 9b). In contrast, the inner structure of the composite solder seam after longterm stressing seems to be less affected when compared with the SAC305 solder seam; only few voids were found. The newly formed Cu-Sn IMCs (darkgray areas) are mainly distributed at the hot side of the solder seam, while only a small quantity of these IMCs were found at the cold side (Fig. 9d). The scanning results illustrate that addition of fullerene reinforcement into solder seam could help to maintain this structural integrity, extending the service life of solder interconnections exposed to a large temperature gradients.

\section{Mechanical properties}

In most previous studies, hardness of composite solder joints containing foreign reinforcements was evaluated using an automatic digital microhardness tester or a Vickers microhardness tester [11, 40-43]. Some researchers tested hardness and modulus of solder joints by employing a nanoindenter [44, 45]. By investigating hardness distribution in solder joints after current stressing, Ren et al. [46] reported that the hardness data showed a gradient distribution within a solder joint from an anode side to a cathode. However, by now, no studies mentioned the effect of thermal gradient on mechanical properties of composite solder joints containing foreign reinforcement. Therefore, in this investigation, to study the mechanical strength of small areas in solders seams, nanoindentor was used to assess a variation in hardness of different solder seams before and after $600 \mathrm{~h} \mathrm{TM}$ stressing. A constant loading rate of $10 \mathrm{mN}$ and a dwell time of $5 \mathrm{~s}$ were set as the operating parameters for these tests. Continuous monitoring of

\begin{tabular}{|l|lll|}
\hline Journal : 10853 - Large 10853 & Dispatch : 21-7-2016 & Pages : 15 \\
& Article No. : 234 & $\square$ LE & $\square$ TYPESET \\
MS Code : JMSC-D-16-02130 & $\square$ CP & $\square$ DISK \\
\hline
\end{tabular}




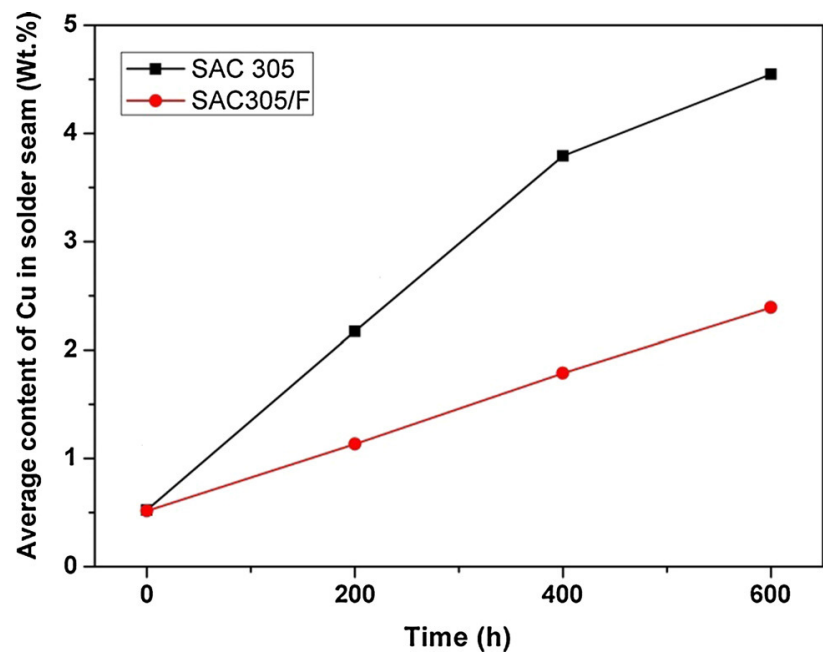

Figure 8 Evolution of weight percentage of $\mathrm{Cu}$ in solder seams with stressing time.
568

569

570

571

572

573

574

575

576

577

578

579

580

581

582

583

584

585

586

587

588

589

590

591

592

593

594

59. AQ1 ment also makes a considerable contribution. The 596 calculated hardness data shown in Firabl 11 also con597 firms this point of view; the average hardness of the 598 fullerene-reinforced composite solder seam was $5 9 \longdiv { A Q 2 } 0 . 2 5 6 \pm 0 . 0 5 \mathrm { GPa }$, which is $21.9 \%$ higher than that of $0.2562 \mathrm{GPa}$ the plain SAC solder. However, it was found that a scatter in load-displacement diagrams for the composite solder seam was larger than that for the plain solder. This phenomenon indicates that the distribution of fullerene in the solder matrix might not be homogeneous. As well known, foreign reinforcement, especially, inert particles (including ceramics and carbon-based materials), are hard to be wetted reactively by the molten solder; there is a large interfacial free energy between the molten solder and the reinforcement. Thus, most of the added reinforcement might be excluded out of the molten solder during the soldering process, leading to a loss of reinforcement and inhomogeneous distributions of reinforcement in solder joints. This problem need to be further studied in the future to facilitate the application of composite solders in the electronic industry.

From Fig. $10 \mathrm{~b}$ and $\mathrm{d}$ as well as the hardness data shown in Table 1, an obvious difference in indenter depths and distributions of hardness data can be found for the two studied types of TM stressed solder seams. These results vividly demonstrate that the hardness data of the plain SAC solder seam after $600 \mathrm{~h}$ stressing gradually decreased from its cold end (area $\mathrm{A}$ ) to the hot end (area $\mathrm{C}$ ), from the average value of $0.2534 \mathrm{GPa}$ for area A to $0.1932 \mathrm{GPa}$ for area C. This phenomenon can also be explained using migration and redistribution of different elements in process, a large amount of $\mathrm{Cu}$ atoms dissolved into the solder seam, forming $\mathrm{Cu}-\mathrm{Sn}$ IMCs; these newly formed $\mathrm{Cu}-\mathrm{Sn}$ IMCs were then continually pushed toward the cold end by the reverse thrust resulted from migration of $\mathrm{Sn}$ atoms from the cold end to the hot one [15]. In addition, like $\mathrm{Cu}$ atoms, $\mathrm{Ag}$ atoms were also confirmed to move in the same direction when the solders were subjected to a large temperature gradient. The migration and redistribution of $\mathrm{Sn}$, $\mathrm{Ag}$, and $\mathrm{Cu}$ during TM stressing would finally lead to an increase of Cu-Sn and Ag-Sn IMCs at the cold end and the central position of the solder seam. This point of view also agrees with the observed results as shown in Figs. 4 and 7a. The elemental redistribution caused by the temperature gradient would largely determine the hardness distribution in the solder seams. According to previous reports, the hardness values of the $\beta-S n, A_{3} S n$, and $\mathrm{Cu}_{6} \mathrm{Sn}_{5}$ phases are estimated as $0.35 \pm 0.04 \mathrm{GPa}$ [47], $2.9 \pm 0.2 \mathrm{GPa}$ [48], and $6.10 \pm 0.53 \mathrm{GPa}[49]$, respectively. It is apparent the solder seam caused by TM stressing. During this
600

601

602

603

604

605

606

607

608

609

610

611

612

613

614

615

616

617

618

619

620

621

622

623

624

625

626

627

628

629

630

631

632

633

634

635

636

637

638

639

640

641

642

643

644

645

646

647

648

649

$\begin{array}{ll}\text { Dispatch : 21-7-2016 } & \text { Pages: } \mathbf{1 5} \\ \square \text { LE } & \square \text { TYPESET } \\ \underset{\text { CP }}{ } & \square \text { DISK }\end{array}$


Figure 9 MCT scanning results for plain $(\mathbf{a}, \mathbf{b})$ and composite (c, d) solder seams before $(\mathbf{a}, \mathbf{c})$ and after $(\mathbf{b}$, d) $600 \mathrm{~h}$ stressing.
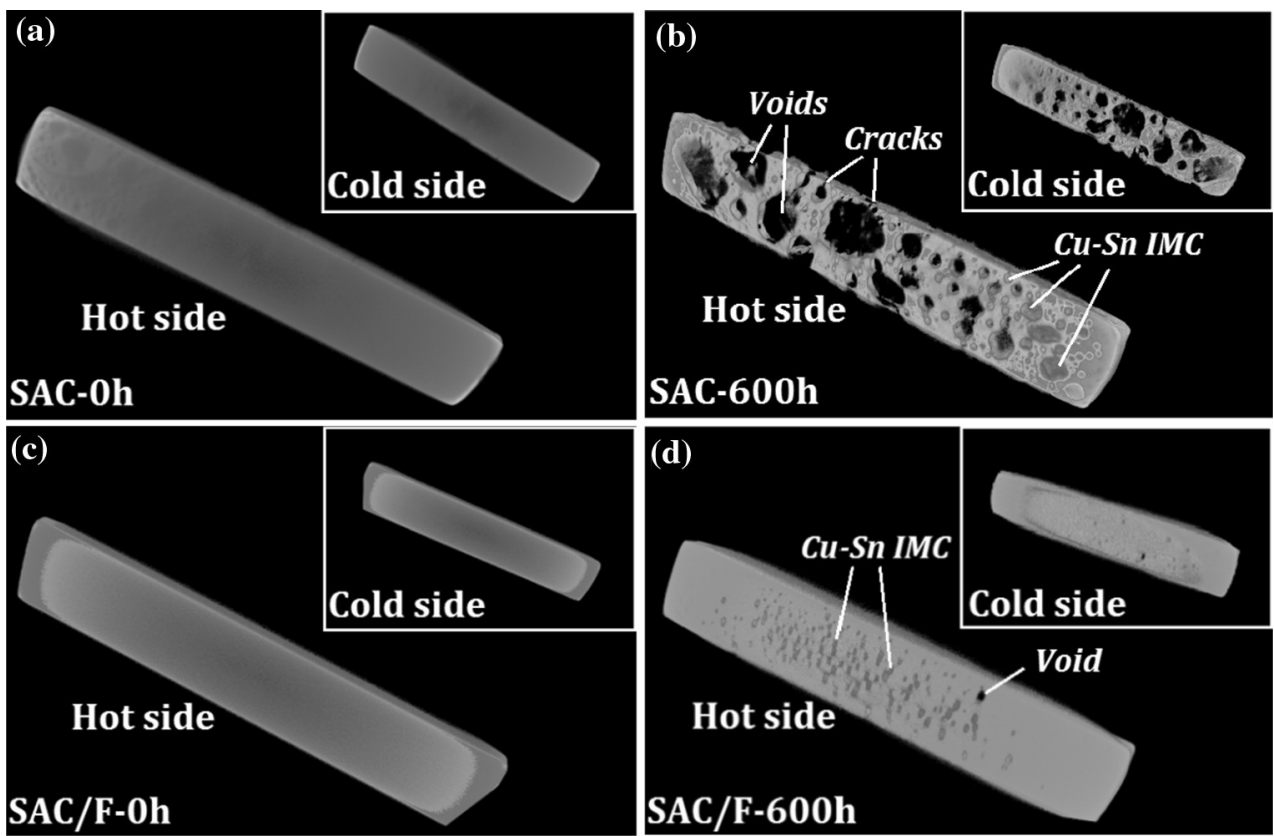
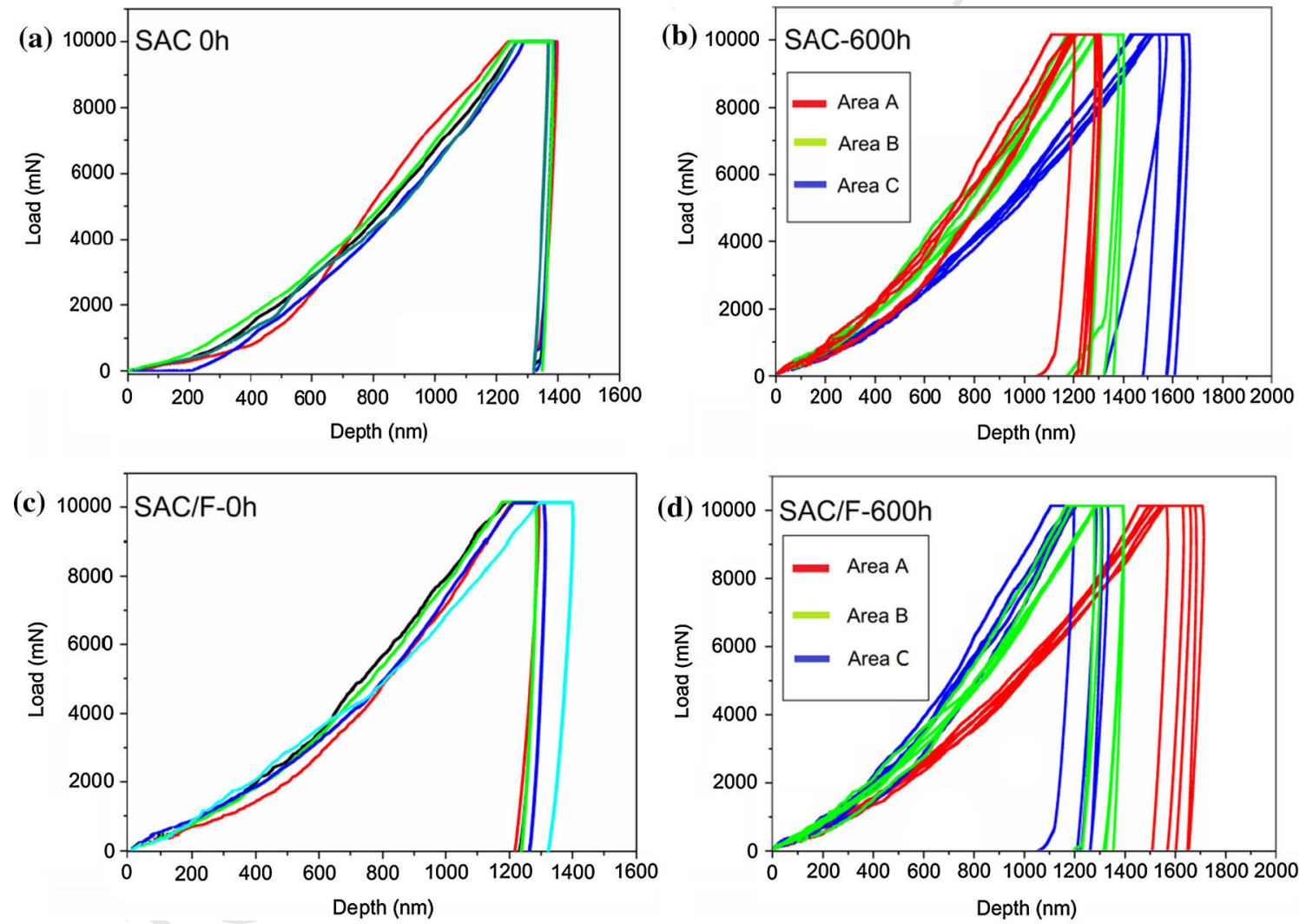

Figure 10 Testing results of indentation points for plain (a, b) and composite (c, d) solder seams before (a, c) and after (b, d) TM for $600 \mathrm{~h}$.

650 that the enrichment of some rigid phase (including $651 \mathrm{Cu}-\mathrm{Sn}$ and Ag-Sn IMCs) at the cold end gave a rise to 652 an improvement of hardness in this area.
In contrast, the distribution of hardness values in the composite solder seam showed an opposite result: the hot end (area $\mathrm{C}$ ) demonstrated a higher
653

\begin{tabular}{|l|ll|}
\hline Journal : 10853 - Large 10853 & Dispatch : 21-7-2016 & Pages : 15 \\
Article No. : 234 & $\square$ LE & $\square$ TYPESET \\
MS Code : JMSC-D-16-02130 & $\checkmark$ CP & $\square$ DISK \\
\hline
\end{tabular}


Table 1 Calculated hardness data for plain (a) and composite (b) solder seams before and after $600 \mathrm{~h} \mathrm{TM}$ stressing

\begin{tabular}{lll}
\hline & Plain SAC solder $(\mathrm{GPa})$ & Composite solder $(\mathrm{GPa})$ \\
\hline Reference Hardness $(0 \mathrm{~h})$ & 0.2102 & 0.2562 \\
Area A $(600 \mathrm{~h})$ & 0.2534 & 0.2026 \\
Area B $(600 \mathrm{~h})$ & 0.212 & 0.2544 \\
Area C $(600 \mathrm{~h})$ & 0.1932 & 0.2634 \\
\hline
\end{tabular}

hardness value than the cold end (area A). In consideration of the migration features of different elements as well as the obtained results shown in Figs. 5 and $7 \mathrm{~b}$, it can be concluded that the migration rate of all elements in the composite solder seam was diminished due to the addition of foreign reinforcement. As described in Sect. 3.2, most of the newly formed Cu-Sn IMCs were located at the central position and the hot end of the solder seam (namely, areas $\mathrm{C}$ and $\mathrm{B}$ ); this was also the main reason for higher hardness values in these areas than in other areas. As for the cold end, although it was also exposed to a large temperature gradient during TM stressing, it was affected more like an isothermal aging process, since the migration rate of elements was largely mitigated. During the stressing period, the decline in hardness resulting from coarsening of the $\beta-S n$ and $\mathrm{Ag}_{3} \mathrm{Sn}$ phases might exceed the enhancement effect caused by enrichment of $\mathrm{Cu}-\mathrm{Sn}$ and Ag-Sn IMCs, leading to the overall decrease in hardness.

\section{Conclusions}

The SAC305/0.1F lead-free composite solder was produced through the powder metallurgy route. A temperature difference generator and relevant $\mathrm{TM}$ samples were designed and prepared; the evaluated temperature gradient in the solder seam in the setup was $1070 \mathrm{~K} / \mathrm{cm}$. After TM stressing, diffusion of $\mathrm{Cu}$ from the substrate to the solder seam was found in both plain and composite solders; this phenomenon was particularly prominent in the unreinforced solder seam. After $600 \mathrm{~h}$ of TM stressing, the interface at the hot end was damaged considerably, while a significant increase in the thickness was found in interfacial IMCs at the cold end. Although interfacial IMCs in the composite solder seam also showed an increasing trend during TM stressing, the interfacial structure remained intact compared with that of the plain solder seam. According to ICP results, the dissolution rate of $\mathrm{Cu}$ in the plain SAC305 solder under the employed experimental condition was $3.1 \times 10^{-6} \mathrm{~g} / \mathrm{h}$; while for the composite solder, it was only $1.22 \times 10^{-6} \mathrm{~g} / \mathrm{h}$. In addition, the scanning MCT results revealed that fullerene reinforcement helped to maintain integrity of the inner structure. The nanoindentation results demonstrated that hardness of the solder alloy obviously improved thanks to the doping of fullerene nanoparticles; moreover, mitigated elemental migration caused by the presence of the reinforcement could alter the distribution of hardness values in a solder seam under TM stressing. The findings of this study indicate that addition of fullerene could mitigate the negative effect of TM; hence, composite solders containing foreign reinforcement have a potential for a use under harsh service conditions.

\section{Acknowledgements}

The authors acknowledge research funding by the National Nature Science Foundation of China (NSFC) and The Research Grants Council (RGC) Joint Research project (NSFC No. 61261160498, RGC No.CityU101/ 12). This research was also supported by the ChinaEuropean Union Technology Cooperation Project (No. 1110) as well as the Marie Curie International Research Staff Exchange Scheme Project within the 7th European Community Framework Programme, (No. PIRSES-GA2010-269113). Thanks are also to the Analytical and Testing Centre at Huazhong University of Science Technology as well as LMCC at Loughborough University for their analytical and testing services.

\section{Compliance with ethical standards}

Conflict of Interest We declare that no conflict of interest exits in the present manuscript.

\section{References}

[1] Ervina EMN, Amares S, Yap TC (2013) A review: influence of nanoparticles reinforced on solder alloy. Solder Surf Mt Tech 25:229-241
696 
[2] Hu X, Chen W, Wu B (2012) Microstructure and tensile properties of $\mathrm{Sn}-1 \mathrm{Cu}$ lead-free solder alloy produced by directional solidification. Mater Sci Eng A 556:816-823

[3] Li Y, Moon K, Wong CP (2005) Electronics without lead. Science 308:1419-1420

[4] Basaran C, Abdulhamid MF (2009) Low temperature electromigration and thermomigration in lead-free solder joints. Mech Mater 41:1223-1241

[5] Chen C, Tong HM, Tu KN (2010) Electromigration and thermomigration in $\mathrm{Pb}$-free flip-chip solder joints. Annu Rev Mater Res 40:531-555

[6] Ye H, Basaran C, Hopkins D (2003) Thermomigration in PbSn solder joints under joule heating during electric current stressing. Appl Phys Lett 82:1045-1047

[7] Ye H, Basaran C, Hopkins D (2004) Mechanical implications of high current densities in flip chip solder joints. Int $\mathrm{J}$ Damage Mech 13:335-346

[8] Basaran C, Ye H, Hopkins D, Frear D, Lin JK (2005) Failure modes of flip chip solder joints under high electrical current density. Trans ASME J Elect Pack 127:157-163

[9] Abdulhamid M, Li S, Basaran C (2008) Thermomigration in lead-free solder joints. Int J Mater Struct Integ 2:11-34

[10] Basaran C, Li S, Abdulhamid M (2008) Thermomigration induced degradation in solder alloys. J Appl Phys 103:123520-123529

[11] Abdulhamid M, Basaran C (2009) Influence of thermomigration on lead-free solder joint mechanical properties. Trans ASME J Electr Pack 131:011002-1-01100212

[12] Abdulhamid M, Basaran C, Lai YS (2009) Thermomigration vs. electromigration in microelectronics solder joints. IEEE Trans Adv Packag 32:627-635

[13] Ma H (2009) Constitutive models of creep for lead-free solders. J Mater Sci 44:3841-3851

[14] Huang ML, Zhou Q, Zhao N, Liu XY, Zhang ZJ (2014) Reverse polarity effect and cross-solder interaction in $\mathrm{Cu} / \mathrm{Sn}-$ $9 \mathrm{Zn} / \mathrm{Ni}$ interconnect during liquid-solid electromigration. J Mater Sci 49:1755-1763

[15] Chen C, Hsiao HY, Chang YW, Ouyang FY, Tu KN (2012) Thermomigration in solder joints. Mater Sci Eng $\mathrm{R}$ 73:85-100

[16] Gao LL, Xue SB, Zhang L, Sheng Z, Ji F, Dai W, Yu SL, Zeng G (2010) Effect of alloying elements on properties and microstructures of Sn-Ag-Cu solders. Microelectron Eng 87:2025-2034

[17] Wang CH, Li KT, Lin CY (2015) Minor Ga addition to effectively inhibit PdSn4 growth between Sn solder and Pd substrate. Intermetallics 67:102-110

[18] Han YD, Jing HY, Nai SML, Xu LY, Tan CM, Wei J (2012) Interfacial reaction and shear strength of Ni-coated carbon nanotubes reinforced $\mathrm{Sn}-\mathrm{Ag}-\mathrm{Cu}$ solder joints during thermal cycling. Intermetallics $31: 72-78$
[19] Sobhy M, El-Refai AM, Mousa MM, Saad G (2015) Effect of ageing time on the tensile behavior of Sn-3.5 wt\% Ag-0.5 $\mathrm{wt} \% \mathrm{Cu}$ (SAC355) solder alloy with and without adding ZnO nanoparticles. Mater Sci Eng A 646:82-89

[20] Chellvarajoo S, Abdullah MZ, Samsudin Z (2015) Effects of $\mathrm{Fe}_{2} \mathrm{NiO}_{4}$ nanoparticles addition into lead free $\mathrm{Sn}-3.0 \mathrm{Ag}$ $0.5 \mathrm{Cu}$ solder pastes on microstructure and mechanical properties after reflow soldering process. Mater Des 67:197-208

[21] Tay SL, Haseeb ASMA, Johan MR, Munroe PR, Quadir MZ (2013) Influence of Ni nanoparticle on the morphology and growth of interfacial intermetallic compounds between Sne3.8Age $0.7 \mathrm{Cu}$ lead-free solder and copper substrate. Intermetallics 33:8-15

[22] Ma LM, Xu GG, Sun J, Guo F, Wang XT (2011) Effects of co additions on electromigration behaviors in $\mathrm{Sn}-3.0 \mathrm{Ag}-$ $0.5 \mathrm{Cu}$-based solder joint. J Mater Sci 46:4896-4905

[23] Bashir MN, Haseeb ASMA, Rahman AZMS, Fazal MA, Kao CR (2015) Reduction of electromigration damage in SAC305 solder joints by adding Ni nanoparticles through flux doping. J Mater Sci 46:6748-6756

[24] He HW, Xu GC, Guo F (2009) Effect of small amount of rare earth addition on electromigration in eutectic $\mathrm{SnBi}$ solder reaction couple. J Mater Sci 44:2089-2096

[25] Zhao R, Ma LM, Zuo Y, Liu SH, Guo F (2013) Retarding electromigration in lead-free solder joints by alloying and composite approaches. J Electron Mater 42:280-287

[26] Hu X, Chan YC, Zhang KL, Yung KC (2013) Effect of graphene doping on microstructural and mechanical properties of $\mathrm{Sn}-8 \mathrm{Zn}-3 \mathrm{Bi}$ solder joints together with electromigration analysis. J Alloy Compd 580:162-171

[27] Guo F, Xu G, He H (2009) Electromigration behaviors in $\mathrm{Sb}$ particle-reinforced composite eutectic $\mathrm{SnAgCu}$ solder joints. J Mater Sci 44:5595-5601

[28] Wang FD, Jin C, Liang H, Tang Y, Zhang H, Yang YJ (2014) Effects of fullerene C60 nanoparticles on A549 cells. Environ Toxicol Phar 37:656-661

[29] Li H, Tee BCK, Cha JJ, Cui Y, Chung JW, Lee SY, Bao Z (2012) High-mobility field effect transistors from large-area solution-grown aligned C60 single crystals. J Am Chem Soc 134:2760-2765

[30] John P, Harris F (1999) Carbon nanotubes and related structures. Cambridge University Press, Cambridge

[31] Calvert P (1999) Nanotube composites: a recipe for strength. Nature 399:210-211

[32] Komatsu K, Murata M, Murata Y (2005) Encapsulation of molecular hydrogen in fullerene C60 by organic synthesis. Science 307:238-240

[33] Chernogorova O, Drozdova E, Ovchinnikova I, Soldatov AV, Ekimov E (2012) Structure and properties of superelastic

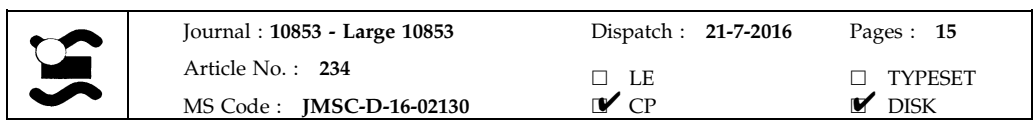


hard carbon phase created in fullerene-metal composites by high temperature-high pressure treatment. J Appl Phys 111:112601-112605

[34] Watanabe H, Fukusumi M, Ishikawa K, Shimizu T (2006) Superplasticity in a fullerene-dispersed $\mathrm{Mg}-\mathrm{Al}-\mathrm{Zn}$ alloy composite. Scripta Mater 54:1575-1580

[35] Chen G, Wu FS, Liu C, Xia W, Liu H (2015) Effects of fullerenes reinforcement on the performance of $96.5 \mathrm{Sn}-$ 3Ag-0.5Cu lead-free solder. Mater Sci Eng A 636:484-492

[36] Huang AT, Gusak AM, Tu KN, Lai YS (2006) Thermomigration in $\mathrm{SnPb}$ composite flip chip solder joints. Appl Phys Lett 88:141911-141913

[37] Ouyang FY, Kao CL (2011) In situ observation of thermomigration of $\mathrm{Sn}$ atoms to the hot end of $96.5 \mathrm{Sn}-3 \mathrm{Ag}-$ $0.5 \mathrm{Cu}$ flip chip solder joints. J Appl Phys 110:123525-123529

[38] Huntington HB (1973) In: Aaronson HI (ed) Diffusion, american society for metals. $\mathrm{OH}$, Metals Park

[39] Chang CW, Yang SC, Tu CT, Kao CR (2007) Cross-interaction between $\mathrm{Ni}$ and $\mathrm{Cu}$ across $\mathrm{Sn}$ layers with different thickness. J Electron Mater 36:1455-1461

[40] Tang Y, Li GY, Pan YC (2014) Effects of $\mathrm{TiO}_{2}$ nanoparticles addition on microstructure, microhardness and tensile properties of $\mathrm{Sn}-3.0 \mathrm{Ag}-0.5 \mathrm{Cu}-\mathrm{xTiO}_{2}$ composite solder. Mater Des 55:574-582

[41] Gain AK, Chan YC, Yung WKC (2011) Microstructure, thermal analysis and hardness of a $\mathrm{Sn}-\mathrm{Ag}-\mathrm{Cu}-1 \mathrm{wt} \%$ nano$\mathrm{TiO}_{2}$ composite solder on flexible ball grid array substrates. Microelectron Reliab 51:975-984

[42] Ping L, Pei Y, Jim L (2008) Effect of SiC nanoparticle additions on microstructure and microhardness of $\mathrm{Sn}-\mathrm{Ag}-$ $\mathrm{Cu}$ solder alloy. J Electron Mater 37:874-879
[43] Chuang TH, Tsao LC, Chung CH, Chang SY (2012) Evolution of $\mathrm{Ag} 3 \mathrm{Sn}$ compounds and microhardness of $\mathrm{Sn} 3.5 \mathrm{Ag} 0.5 \mathrm{Cu}$ nano-composite solders during different cooling rate and aging. Mater Des 39:475-483

[44] Chellvarajoo S, Abdullah MZ, Khor CY (2015) Effects of diamond nanoparticles reinforcement into lead-free $\mathrm{Sn}-$ $3.0 \mathrm{Ag}-0.5 \mathrm{Cu}$ solder pastes on microstructure and mechanical properties after reflow soldering process. Mater Des 82:206-215

[45] Yang Z, Zhou W, Wu P (2014) Effects of Ni-coated carbon nanotubes addition on the microstructure and mechanical properties of $\mathrm{Sn}-\mathrm{Ag}-\mathrm{Cu}$ solder alloys. Mater Sci Eng, A 590:295-300

[46] Ren F, Xu LH, Zhang X, Pang HL, Tu KN (2006) In-Situ Study of the Effect of electromigration on strain evolution and mechanical property change in lead-free solder joints, 56th Electronic Components and Technology Conference, San Diego, 2006. pp. 0569-5503

[47] Sadiq M, Lecomte JS, Cherkaoui M (2013) Nanoindentation for measuring individual phase mechanical properties of SnAg-Cu lead-free solders incorporating pileup effects. Chaotic Model and Simul 2:335-348

[48] Chromik RR, Vinci RP, Allen SL, Notis MR (2003) Nanoindentation measurements on $\mathrm{Cu}-\mathrm{Sn}$ and $\mathrm{Ag}-\mathrm{Sn}$ intermetallics formed in $\mathrm{Pb}$-free solder joints. J Mater Res 18:2251-2261

[49] Jang GY, Lee JW, Duh JG (2004) The nanoindentation characteristics of $\mathrm{Cu}_{6} \mathrm{Sn}_{5}, \mathrm{Cu}_{3} \mathrm{Sn}$, and $\mathrm{Ni}_{3} \mathrm{Sn}_{4}$ intermetallic compounds in the solder bump. $\mathrm{J}$ Electron Mater 33:1103-1110

$\begin{array}{lll}\text { Journal : } \mathbf{1 0 8 5 3} \text { - Large 10853 } & \text { Dispatch : 21-7-2016 } & \text { Pages : } \mathbf{1 5} \\ \text { Article No. : } \mathbf{2 3 4} & \square \text { LE } & \square \text { TYPESET } \\ \text { MS Code : JMSC-D-16-02130 } & \checkmark \text { CP } & \square \text { DISK }\end{array}$


Journal : 10853

Article : 234

\section{Author Query Form}

\section{算 Springer}

the language of science

\section{Please ensure you fill out your response to the queries raised below and return this form along with your corrections}

\section{Dear Author}

During the process of typesetting your article, the following queries have arisen. Please check your typeset proof carefully against the queries listed below and mark the necessary changes either directly on the proof/online grid or in the 'Author's response' area provided below

\begin{tabular}{|l|l|l|}
\hline Query & Details Required & Author's Response \\
\hline AQ1 & Figure 11 had been cited in the text, but not provided, kindly check and amend the changes. & \\
\hline AQ2 & Please check the edits made in the article title and amend if necessary. & \\
\hline
\end{tabular}

Author's Response

AQ1: "Fig 11"s were changed to "Table 1", please see line 580 and 593

AQ2: "0.256 $0.05 \mathrm{GPa}$ " was changed to "0.2562 GPa". 